\title{
Experimental study on elastic modulus and Poisson's ratio of EPP load-bearing insulation concrete

\author{
Huanqin Cai ${ }^{1}$ a Mingyu $\mathrm{Li}^{1, \mathrm{~b}}$, Jiansuo $\mathrm{Ma}^{1}$, Lan Cheng ${ }^{1}$ and Teng Guo ${ }^{1}$ \\ ${ }^{1}$ University of Architecture, Zhangjiakou, Hebei, China. \\ a564623171@qq.com, bjggc2015@126.com
}

\begin{abstract}
Keywords: EPP particles; Load-bearing insulating concrete; Elastic modulus; Poisson's ratio Abstract. EPP load-bearing insulation concrete is prepared by adding EPP particles into the cement mortar matrix.In order to study the deformation performance of three kinds of EPP load-bearing concrete with different strength grades, the axial compression test of EPP load-bearing concrete is carried out.The experimental results show that the elastic modulus and poisson's ratio decrease with the decrease of compressive strength, but the plasticity increases gradually.The experimental value of elastic modulus is higher than that of empirical formula, and according to the empirical formula of elastic modulus, the formula of elastic modulus of EPP load-bearing insulation concrete is obtained.
\end{abstract}

\section{Introduction}

With the increase of construction consumption in China, building energy conservation has become the focus of attention. The thermal conductivity of ordinary concrete is high, and its thermal insulation performance can not meet the requirements of building energy saving[1].

The organic particle EPP was incorporated into the mortar matrix material to achieve the performance of concrete insulation and load-bearing performance.The elastic modulus and Poisson's ratio are important basis for checking the concrete deformation and crack[2,3], therefore, the research and analysis of the deformation performance of EPP bearing thermal insulation concrete is of great practical significance for the practical application of this new building material.

\section{Testing of Raw Materials and Test Instruments}

Cement: Jinyu brand P.O42.5 cement produced by Zhangjiakou Jinyu Cements Limited.

Fly ash: class I fly ash produced by Zhangjiakou shalingzi power plant.

Silica fume: the silica fume produced in Henan Yuan Heng material plant, its $\mathrm{SiO}_{2}$ content is more than $95 \%$.

River sand: river sand in zhangjiakou area, the fineness modulus is 2.71 , the apparent density is $2604 \mathrm{~kg} / \mathrm{m}^{3}$ cubed, the density is $1667 \mathrm{~kg} / \mathrm{m}^{3}$ cubed, middle sand.

Iron tailings: iron tailings produced by a steel mill in Hebei province. The fineness modulus is 2 , the absorption rate is $3.1 \%$, and the accumulation density is $1734 \mathrm{~kg} / \mathrm{m}^{3}$ cubed, and the apparent density is $2958 \mathrm{~kg} / \mathrm{m}^{3}$.

EPP particles: EPP particles are produced by Beijing Zhongxing new plastic machinery manufacturing Co., Ltd. The physical properties and particle characteristics of EPP particles are shown in table 1 and figure 1.

Water: pure water.

Modifier: modifier produced by Qingdao Uoso Chemical Technology Co., Ltd., light yellow viscous liquid, the content of $99 \%$.

Water reducing agent: polycarboxylic acid efficient water reducing agent is produced by zhangjiakou HaiFeng new building materials co., LTD., with a reduction rate of $25 \%$.

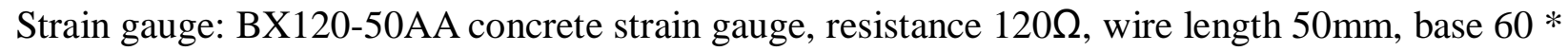
$8 \mathrm{~mm}$, sensitivity coefficient of 2.0 .

The instrument used in this experiment is WHY-2000kN microcomputer controlled electro hydraulic servo universal testing machine. 
Table 1 Physical properties and particle characteristics of EPP particles

\begin{tabular}{ccccccc}
\hline $\begin{array}{c}\text { Type of EPP } \\
\text { particles }\end{array}$ & $\begin{array}{c}\text { Foaming } \\
\text { ratio } \\
\text { (times) }\end{array}$ & $\begin{array}{c}\text { particle } \\
\text { size } \\
(\mathrm{mm})\end{array}$ & $\begin{array}{c}\text { Packing } \\
\text { density } \\
\left(\mathrm{kg} / \mathrm{m}^{3}\right)\end{array}$ & $\begin{array}{c}\text { Apparent } \\
\text { density } \\
\left(\mathrm{kg} / \mathrm{m}^{3}\right)\end{array}$ & $\begin{array}{c}\text { Void } \\
\text { fraction } \\
(\%)\end{array}$ & Surface characteristics \\
\hline $\begin{array}{c}\text { Original EPP } \\
\text { particles }\end{array}$ & 15 & 2.5 & 50 & 60 & 16.7 & $\begin{array}{c}\text { Flat spherical, smooth, } \\
\text { hydrophobic } \\
\text { Original EPP } \\
\text { particles }\end{array}$ \\
$\begin{array}{c}\text { Original EPP } \\
\text { particles }\end{array}$ & 30 & 3.5 & 25 & 30 & 16.7 & $\begin{array}{c}\text { Flat spherical, smooth, } \\
\text { hydrophobic } \\
\text { Flat spherical, smooth, } \\
\text { hydrophobic }\end{array}$ \\
\hline
\end{tabular}

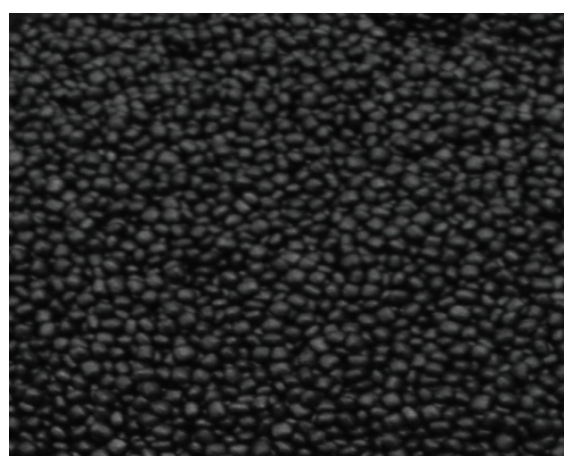

Fig.1 EPP particles

\section{Experimental Research Scheme}

Proportion Design. The strength of the concrete mortar matrix material is C60, and EPP load-bearing insulation concrete is the modified EPP particle, which is mixed into the mortar by $45 \%, 55 \%$ and $65 \%$ respectively. When EPP was modified, the dosage of the modified triethanolamine solution was $3 \%$ of EPP particle quality, and the cement package was twice as much as the EPP particle. The specific data is shown in table 2.

Specimen Production. According to the requirement of mix proportion, weigh cement, fly ash, tailings sand, river sand and put in agitator respectively. In order to mix well, mix the mixer slowly $(125 \mathrm{R} / \mathrm{min}) 120 \mathrm{~s}$. Pour the water reducer into the water, mix the water and water mixture thoroughly, and then disperse the water reducer in the water, and mix the mixture into the mixture for 30 seconds. To accelerate the action of water reducing agent, use fast stirring $(285 \mathrm{R} / \mathrm{min})$ 60s. Then the modified EPP particles are added to the mixer to stop stirring slowly for $120 \mathrm{~s}$.

The EPP load-bearing insulation concrete was put into the test mold of $100 \mathrm{~mm} * 100 \mathrm{~mm} * 300 \mathrm{~mm}$, and the mold was removed after 24 hours of maintenance in the standard curing room. The specimens were maintained for $28 \mathrm{~d}$,each sample with the ratio of 6 specimens.

Table 2 EPP load-bearing insulation concrete mix ratio

\begin{tabular}{|c|c|c|c|c|c|c|c|c|c|c|}
\hline \multirow{2}{*}{$\begin{array}{l}\text { Compres } \\
\text { sive } \\
\text { strength } \\
\text { level }\end{array}$} & \multirow{2}{*}{$\begin{array}{l}\text { Cement } \\
\left(\mathrm{kg} / \mathrm{m}^{3}\right)\end{array}$} & \multirow{2}{*}{$\begin{array}{l}\text { Fly ash } \\
\left(\mathrm{kg} / \mathrm{m}^{3}\right)\end{array}$} & \multirow{2}{*}{$\begin{array}{l}\text { Silica } \\
\text { fume } \\
\left(\mathrm{kg} / \mathrm{m}^{3}\right)\end{array}$} & \multirow{2}{*}{$\begin{array}{c}\text { River } \\
\text { sand } \\
\left(\mathrm{kg} / \mathrm{m}^{3}\right)\end{array}$} & \multirow{2}{*}{$\begin{array}{c}\text { Iron } \\
\text { tailings } \\
\text { sand } \\
\left(\mathrm{kg} / \mathrm{m}^{3}\right)\end{array}$} & \multicolumn{3}{|c|}{ EPP particles } & \multirow{2}{*}{$\begin{array}{c}\text { Water } \\
\left(\mathrm{kg} / \mathrm{m}^{3}\right)\end{array}$} & \multirow{2}{*}{$\begin{array}{c}\text { Water } \\
\text { reducing } \\
\text { agent } \\
\left(\mathrm{kg} / \mathrm{m}^{3}\right)\end{array}$} \\
\hline & & & & & & $\begin{array}{c}5 \\
\mathrm{~mm}\end{array}$ & $\begin{array}{l}3.5 \\
\mathrm{~mm}\end{array}$ & $\begin{array}{l}2.5 \\
\mathrm{~mm}\end{array}$ & & \\
\hline $\mathrm{C} 20$ & 365 & 104 & 52 & 469 & 313 & 3.7 & 4.1 & 2.7 & 151 & 4.4 \\
\hline $\mathrm{C} 15$ & 306 & 87 & 44 & 394 & 262 & 4.4 & 4.9 & 3.3 & 127 & 3.7 \\
\hline C10 & 260 & 74 & 37 & 334 & 223 & 5.3 & 5.9 & 3.9 & 108 & 3.2 \\
\hline
\end{tabular}

Test Method. The test is based on the "test method of mechanical properties of ordinary concrete"[4]GB/T50081-2002.The surface of the cured specimen was wiped clean, the transverse 
and longitudinal strain gages were pasted on the two opposite sides, the two transverse strain gages were used to determine the lateral deformation of the prism, and the two opposite longitudinal strain gages were measured before cracking vertical strain data. Glue paste diagram shown in figure 2 .

Before the test, using a dry towel to wipe the upper and lower surfaces of the specimen and the pressure plate surface. Place the specimen upright on the steel plate of the testing machine with the center aligned and the wire connected to the strain gauge. Debugging strain collection system to ensure its normal work, the strain gauge after each channel to debug loading.First, with $0.8 \mathrm{kN} / \mathrm{s}$ load until the specimen damage, measured the axial compressive strength $f_{c}$. Load to $1 \mathrm{kN} / \mathrm{s}$ loading speed to $0.5 f_{c}$ uninstall, Repeat 5 times and record the test data.The axial compression test of EPP load-bearing insulation concrete prism is shown in figure 3 .

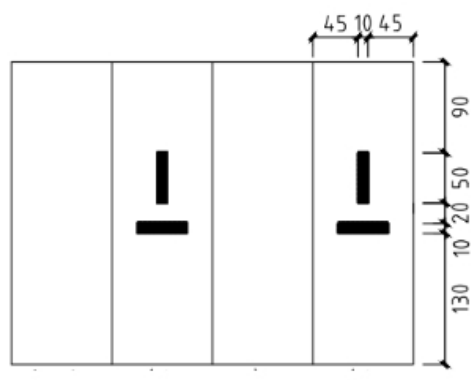

top side bottom side

Fig.2 pasting schematic diagram of strain gauge

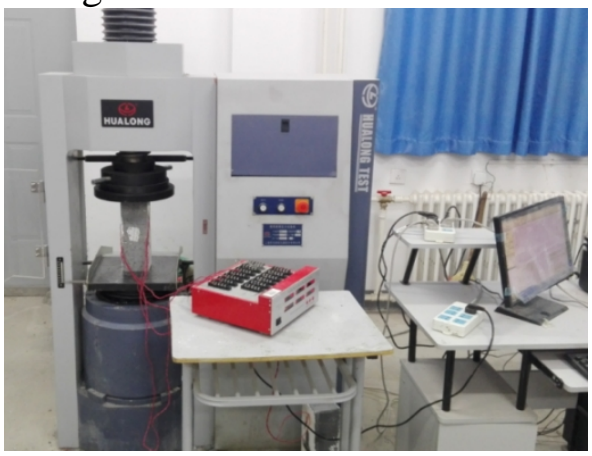

Fig.3 EPP load-bearing insulation concrete axial compression test

\section{Test Results and Analysis}

Elastic Modulus. According to the record data of the strain gauge, the average value of the longitudinal and lateral strain is taken as the final result. The formula for calculating of the elastic modulus is as follows

$$
E=\sigma_{a} / \varepsilon_{a}
$$

$\sigma_{a}-$ The corresponding stress value of the elastic phase;

$\varepsilon_{a}-$ The strain value corresponding to the elastic phase.

The American concrete association aci318-95 and ACI213R committee concluded that the calculation formula of elastic modulus of lightweight aggregate concrete was

$$
E_{c}=0.043 \rho_{c}{ }^{1.5} \sqrt{1.2 f_{c u, k}^{\prime}} .
$$

"lightweight aggregate and lightweight aggregate concrete technical requirements and test methods" (JGJ51-78) in the formula for calculating the elastic modulus converted is as follows

$$
E_{c}=1.99 \rho \sqrt{f_{c u, k}} .
$$

$f_{c u, k}$-Compressive strength of concrete cubical specimens.

The formula for calculating the modulus of elasticity of the technical specification for lightweight aggregate concrete (JGJ51 - 90) is as follows

$$
E_{c}=2.02 \rho_{c} \sqrt{f_{c u}} .
$$


$E_{c}$ - Elastic modulus of lightweight aggregate concrete (MPa)

$\rho_{c}$ - Apparent density of lightweight aggregate concrete $\left(\mathrm{kg} / \mathrm{m}^{3}\right)$

$f_{c u}$-Compressive strength standard value of lightweight aggregate standard cubes $(150 \mathrm{~mm} *$ $150 \mathrm{~mm} * 150 \mathrm{~mm})(\mathrm{MPa})$.

$E_{c}$ is elastic modulus of ordinary concrete, $f_{c u, k}$ is standard cube compressive strength standard value of ordinary concrete $(\mathrm{MPa})$.

$$
f_{c u, k}=f_{c u}-1.645 \sigma \text {. }
$$

when the concrete design strength is lower than C20, take 4MPa.

The results of testing the modulus of elasticity and the results of the calculation are summarized as shown in table 3.

Table 3 Elastic modulus test results and calculation results summary table

\begin{tabular}{cccccccc}
\hline $\begin{array}{c}\text { Strength } \\
\text { grade }\end{array}$ & $\begin{array}{c}\text { Apparent } \\
\text { density } \\
\left(\mathrm{g} / \mathrm{cm}^{3}\right)\end{array}$ & $\begin{array}{c}\text { Compressive } \\
\text { strength } \\
(\mathrm{MPa})\end{array}$ & $\begin{array}{c}\text { Elastic } \\
\text { modulus } \\
\text { test value } \\
(\mathrm{MPa})\end{array}$ & $\begin{array}{c}\text { Formula } \\
(2) \\
\text { calculates } \\
\text { the value } \\
(\mathrm{MPa})\end{array}$ & $\begin{array}{c}\text { Formula } \\
(3) \\
\text { calculates } \\
\text { the value }\end{array}$ & $\begin{array}{c}\text { Formula } \\
(4) \\
\text { calculates } \\
\text { the value }\end{array}$ & $\begin{array}{c}\text { Formula } \\
\text { calculates } \\
\text { the value }\end{array}$ \\
\hline $\mathrm{C} 20$ & 1595 & 22.28 & 21869 & 11940 & 13835 & 14044 & 21831 \\
$\mathrm{C} 15$ & 1478 & 16.53 & 16704 & 8464 & 10189 & 10342 & 16077 \\
$\mathrm{C} 10$ & 1290 & 11.9 & 12499 & 5040 & 6494 & 6592 & 10247 \\
& & & $50.18 \%$ & $40.25 \%$ & $39.34 \%$ & $5.71 \%$ \\
\hline
\end{tabular}

From table 3, it can be found that there is a big error between the experimental measurement results and the empirical formula calculation results. Therefore, it is necessary to formulate the formula of the elastic modulus of EPP load-bearing concrete.The test values of the elastic modulus of EPP load-bearing insulation concrete are close to those calculated by "Lightweight Aggregate Concrete Technical Specification" (JGJ51-90), Therefore, the elastic modulus to be fitted to the formula as its prototype, The regression model is $E_{c}=2.02 \alpha \rho \sqrt{f_{c u, k}}, \alpha$ is regression coefficient.According to the test results, the value was 1.69 , Therefore, the fitting formula of the elastic modulus of EPP load-bearing insulation concrete is as follows

$$
E=3.14 \rho \sqrt{f_{c u, k}}
$$

The elastic modulus using the fitting formula(6) calculations are shown in Table 3 , the calculation results compared to the empirical formula of the relative error is reduced to $5.71 \%$ of its calculated value, visible fitting effect is relatively ideal.

Poisson's Ratio. The ratio of the data to the lateral strain and the longitudinal strain when the compressive stress is $0.2 \mathrm{fc}$ is used as a Poisson's ratio. The calculation formula is as follows

$$
\mu=\varepsilon_{\text {lat }} / \varepsilon_{a x} .
$$

$\varepsilon_{\text {lat }}$ - The absolute value of the transverse strain difference corresponding to the elastic phase;

$\varepsilon_{a x}$ - The absolute value of the longitudinal strain difference corresponding to the elastic phase.

The results of the test are shown in table 4. 
Table 4 Test results of Poisson ratio for EPP bearing insulation concrete with different strength grades

\begin{tabular}{ccccccccc}
\hline \multicolumn{2}{c}{ C20 } & \multicolumn{9}{c}{ C15 } & \multicolumn{3}{c}{ C10 } \\
\hline $\begin{array}{c}\text { Transverse } \\
\text { strain }\end{array}$ & $\begin{array}{c}\text { Longit } \\
\text { udinal } \\
\text { strain }\end{array}$ & $\begin{array}{c}\text { Poisson } \\
\text { ratio }\end{array}$ & $\begin{array}{c}\text { Transverse } \\
\text { strain }\end{array}$ & $\begin{array}{c}\text { Longitu } \\
\text { dinal } \\
\text { strain }\end{array}$ & $\begin{array}{c}\text { Poisson } \\
\text { ratio }\end{array}$ & $\begin{array}{c}\text { Transverse } \\
\text { strain }\end{array}$ & $\begin{array}{c}\text { Longit } \\
\text { udinal } \\
\text { strain }\end{array}$ & $\begin{array}{c}\text { Poisson } \\
\text { ratio }\end{array}$ \\
46 & 205 & 0.268 & 51 & 185 & 0.276 & 48 & 171 & 0.281 \\
38 & 182 & 0.253 & 40 & 151 & 0.265 & 63 & 240 & 0.262 \\
40 & 143 & 0.266 & 40 & 142 & 0.282 & 45 & 174 & 0.259 \\
62 & 154 & 0.26 & 56 & 216 & 0.259 & 43 & 158 & 0.272 \\
41 & 161 & 0.251 & 54 & 208 & 0.26 & 52 & 187 & 0.278 \\
average value & 0.255 & 34 & 134 & 0.254 & 39 & 138 & 0.283 \\
\hline
\end{tabular}

It can be seen from table 4 that the ratio of Poisson's ratio increases with the decrease of the strength of EPP bearing insulation concrete. The main reason is that the elastic modulus of EPP particles is relatively low. With the increase of EPP particle content, the lateral deformation constraint decreases. Under the same longitudinal strain, the lateral strain increases rapidly, leading to the more obvious transverse deformation and the larger Poisson's ratio.

\section{Conclusion}

With the increase of the content of EPP particles, the modulus of elasticity of concrete and Poisson's ratio gradually decrease, which shows better deformation performance.

Through the test, it is found that the error of calculating the elastic modulus of the EPP bearing insulation concrete is larger by using the empirical formula. According to the experimental data, the formula of elastic modulus of EPP load-bearing thermal insulation concrete is fitted with the empirical formula as a prototype, which has certain pertinence and accuracy.

The test results show that the elastic modulus of C20, C15 and C10EPP is $21869 \mathrm{MPa}$, $16704 \mathrm{MPa}$ and $12499 \mathrm{MPa}$, respectively. The ratio of Poisson's ratio is $0.259,0.266$ and 0.272 respectively. The experimental data will provide the basis for the internal force analysis and the calculation of the deformation properties of the concrete structural members.

\section{Acknowledgements}

This work was financially supported by Key scientific research project of Hebei Provincial Education Department(ZD2015132)

\section{Reference}

[1] Zhang Zeping. Basic performance test and theoretical analysis of vitrified microbead insulation concrete and its structure. edtied by Taiyuan University of Technology, TaiYuan,(2009).

[2] Jiang Zhengwu, Zhou Lei, Li Wenting. Study on the correlation of elastic modulus and strength of limestone aggregate concrete. submitted to Journal of construction materials(2014).

[3] Guo Yuanchen, Wang Xue. Experimental study of elastic modulus of recycled aggregate concrete. submitted to Portland bulletin(2013). 
[4] Junming Rong,etc. Standard of testing methods for mechanical properties of ordinary concrete . edtied by China Construction Industry Press, Bei Jing,(2003). 